\title{
DEVELOPMENT DYNAMIC OF HEALTHY LIFE STYLE PERSONALITY COMPONENT IN RELATIVELY HEALTHY STUDENTS
}

Kudryavtsev M.D. ${ }^{1,2,5}$, Kramida I.E. ${ }^{2}$, Iermakov S.S. ${ }^{3}$, Osipov A.Yu. ${ }^{1,4}$

${ }^{1}$ Siberian Federal University, Russia

${ }^{2}$ Siberian State Aerospace University, Russia

${ }^{3}$ Kazimierz Wielki University in Bydgoszcz, Poland

${ }^{4}$ V.F. Voino-Yasenetsky Krasnoyarsk State Medical University, Russia

${ }^{5}$ Krasnoyarsk State Pedagogical University of V.P. Astafyev, Russia

\begin{abstract}
Purpose: to determine effectiveness of different physical culture trainings for development of students' healthy life style personality components. Material: $1^{\text {st }}-3^{\text {rd }}$ year students, trained at physical culture lessons, participated in the research. All students related to main health group (students, having no health problems). In total 803 students participated in the research. The testing was conducted in periods from 2001 to 2005 and from 2010 to 2015. Results: positive changes of different personality's component of healthy life style were observed. Parameters of emotional stability and tolerance were found. Teaching in last years develops personality's components to less extent. The highest changes were determined in $3^{\text {rd }}$ year students, independent on the program of their training. We did not find differences in degree of trainings' influence of specialized and typical classes. Conclusions: at trainings it is necessary to pay more attention to development personality's components of healthy life style, especially emotional stability and tolerance in respect to other people.
\end{abstract}

Key words: students, physical culture, specialization, healthy life style, personality.

\section{Introduction}

Specialists' training at high quality implies provisioning students with certain amount of knowledge, formation and development of workable personality. Personality's effective functioning is impossible without his/her healthy life style (HLS). The most frequent HLS is understood as healthy behavior: regular motor functioning; correct eating; useful habits, connected with correct day regime and alternation of work and rest; absence of harmful habits $[8,24,32]$. Such understanding of human HLS is restricted with by regarding human life as life of his physical body. However, human being is not only body. Human HLS shall include his healthy soul. Thus, human HLS includes: healthy behavior and thinking; healthy emotions; harmony in relations with surrounding world and own self [27]. That is why it is necessary to study behavioral base of human HLS; HLS of his/her mental component and personality's components. Especially it concerns the problems of formation and development of HLS personality components in the process of students' study at HEE.

Personality's components of HLS can be understood as human personality qualities, which characterize healthy thinking and harmony of human behavior and relations with surrounding world and him/her self (positive state); tolerant attitude to other people (tolerance); self-confidence, based on positive attitude towards hum/herself (confidence); ability to be in any situation emotionally positive that is an important factor of stress-resistance (emotional stability) [18]; vital activity, which characterizes personality's orientation on positive functioning (activity).

Each of enlisted five positive qualities of a student is integral one. It includes several particular characteristics - features of character or person's abilities. The list of particular characteristics of HLS every integral personality's component is give in $[13,14]$.

In the process of study at HEE personality components of students' HLS develop differently. It is necessary to regard as positive such changes, under which the enlisted above five qualities strengthen.

Recent years, in practice new principle of physical culture (PC) trainings' organization (in respect to relatively healthy students, MHG-main health group) has been being applied [13]. Students can choose typical physical culture trainings or one of specializations (power training, swimming, shaping or outdoor games) and

(C) Kudryavtsev M.D., Kramida I.E. lermakov S.S., Osipov A.Yu., 2016 doi:10.15561/20755279.2016.0603 
attend classes as per schedule of the chosen direction. Such approach permitted to increase students' interest to trainings, their responsibility; decrease missing of classes. However the influence of such trainings' organization on development of relatively healthy students' HLS personality components still remains to be an open question.

Recent years rather a high number of scientific works on different kinds of sports and health related systems has appeared $[6,30,39,43]$. Some works are devoted to training of physical $[9,31,33]$ and psychophysical $[9,38,40,41]$ abilities of different specialties students. But development of HLS personality components in the process of study at HEE is not regarded in these works. Some authors study formation of professionally significant qualities in different specialties' students by means of physical culture and sports (the works by N.A. Aleshev are the closest to us by topics) [2]). However, these authors do not study the problem of students' personality development (and more over - about development of their HLS personality components) in conditions of different PC organization: by typical program or by specializations.

In the course of our research we found the following main contradictions:

- Between active propaganda of healthy life style theory and practice and main directions of physical culture trainings' substantiation in modern society. It is connected with searching and opening new effective health related technologies and directions;

- Between theoretical substantiation of demand in strengthening students' motivation for healthy life style and actual situation as on to day. It is connected with insufficient quantity of physical culture motivated trainings;

- Between declaration healthy life style different elements' implementation in physical culture discipline and absence of specially worked out for students training programs. Such programs shall be based on application modern means for student' health improvement. Such programs shall facilitate actual increment of students, practicing healthy life style.

Recent years there have been observed unsubstantiated reduction of time for physical culture and quantity of youth, preferring sports or physical exercises to passive leisure [3, 35, 36, 42]. In this aspect we can mark out several works on the following problems: positive changes in students' personality [16, 17, 34]; HLS personality components in students of different health groups [14, 15, 37]. But some problems of dynamic of HLS personality components' development in students, trained by PC typical program and by specialization are being still unsolved. Besides, it is necessary to seek more effective variants of students' PC training.

The purpose of the work is to substantiate and perfect approaches to development of students' HLS personality components by means of physical culture trainings during three years of heir study.

The tasks of the research:

1. To fulfill comparative analysis of positive changes in HLS personality components of relatively healthy students, who are trained by at $1^{\text {st }}-3^{\text {rd }}$ years: a) by typical program (PC specialization); b) by specialization programs (PS (practicing sports) specialization).

2. To fulfill comparative analysis of HLS personality components' changes in relatively healthy students in periods from 2001-2005 and from 2010 to 2015.

\section{Material and methods}

Participants: $1^{\text {st }}-3^{\text {rd }}$ year students, trained at physical culture lessons, participated in the research. All students related to main health group (students, having no health problems). For participation in the research we selected students, who actively attended physical culture classes. The students were combined in different groups: 2001-2005 and 2010-2015 years of study. These groups are marked in the following way (below, in brackets there are volumes of samples for groups of 2001-2005 and 2010-2015 accordingly): 1, 2, 3- RHS (relatively healthy students) 1 (146 and 193 persons), 2 (163 and 83persons), 3 (46 and 50persons), who attended PC typical classes; ) $1 c, 2 c, 3 c$ - RHS 1 (31persons), 2 (41persons), 3 (50 persons), who attended specialized trainings in 2010 2015.

Organization of the research:

The questioning was conducted in academic groups of $1^{\text {st }}-3^{\text {rd }}$ year students at the end of academic year. Questionnaires consisted of personality's main positive characteristics, located in free order. Students assessed (by 
scale from 0 to 10 points) the degree of every characteristic in them at the beginning and at the end of study period [19].

Statistical analysis: confidence of differences between values was assessed by Student's t-criterion (at significance level less than 0.05). The differences were interpreted as tendency at significance level more than 0.05 , but less than 0.15 (in the table below such cases are marked with *). The received data were processed with the help of Microsoft Excel program.

\section{Results of the research}

The main results of students' questioning are given in summarizing table.

Table. Average increment of students' HLS personality componentsT for study period

\begin{tabular}{|c|c|c|c|c|c|c|c|c|c|c|}
\hline \multirow{2}{*}{ Personality qualities } & & \multirow{2}{*}{ Years } & \multicolumn{6}{|c|}{$\begin{array}{l}\text { Increment of marks }+\left(\begin{array}{ll}0-10\end{array}\right) \\
\text { points }\end{array}$} & \multicolumn{2}{|c|}{ Important significant correlations } \\
\hline & & & 1 & $1 c$ & 2 & $2 c$ & 3 & $3 c$ & $\begin{array}{l}\text { For every period of } \\
\text { years }\end{array}$ & In dynamic \\
\hline \multirow{2}{*}{ Positive state } & 1 & 2001-2005 & 0.6 & & 0.6 & & 1.0 & & '3’>1', 2 & \multirow{2}{*}{$\begin{array}{l}{ }^{\prime} 31^{\prime} *>{ }^{\prime} 3{ }^{\prime} \\
{ }^{\prime} 1_{1}>12^{\prime}, ' 1 c\end{array}$} \\
\hline & 2 & 2010-2015 & 0.2 & 0.2 & 0.4 & 0.3 & 0.7 & 0.9 & ${ }^{`} 3,3 c^{\prime}>$ (other) & \\
\hline \multirow{2}{*}{ Tolerance } & 1 & 2001-2005 & 0.2 & & 0.2 & & 0.6 & & 3’>1', '2' & \multirow{2}{*}{${ }^{\prime} 31^{\prime}>{ }^{\prime} 3 c^{\prime}$} \\
\hline & 2 & 2010-2015 & 0.1 & 0.0 & 0.1 & 0.1 & 0.4 & 0.2 & ${ }^{\prime} 3^{\prime}>\left(\right.$ all, except $\left.{ }^{`} 3 c^{\prime}\right)$ & \\
\hline \multirow[b]{2}{*}{ Self-confidence } & 1 & 2001-2005 & 0.6 & - & 0.7 & - & 1.0 & - & $3>^{\prime} 11^{\prime} 2$ & \multirow[b]{2}{*}{$\begin{array}{l}1_{1}^{\prime}>{ }^{\prime} 1_{2}^{\prime} \\
3_{1}^{\prime}>{ }^{\prime}{ }_{2}^{\prime}\end{array}$} \\
\hline & 2 & 2010-2015 & 0.3 & 0.5 & 0.8 & 0.5 & 0.7 & 0.8 & $\begin{array}{l}2^{\prime}, 3^{\prime}, 3 c^{\prime}>{ }^{\prime} \\
2^{\prime}>{ }^{\prime} 2 c^{\prime *}\end{array}$ & \\
\hline \multirow{2}{*}{ Activity } & 1 & 2001-2005 & 0.5 & - & 0.6 & - & 1.0 & - & ‘’>1', 2 & \multirow{2}{*}{$3_{1}^{\prime}>{ }^{\prime} 32^{\prime}, 3 c^{\prime}$} \\
\hline & 2 & 2010-2015 & 0.4 & 0.3 & 0.5 & 0.4 & 0.6 & 0.7 & ${ }^{\prime} 3 c^{\prime}>{ }^{\prime} 1{ }^{\prime}, 1 c^{\prime}$ & \\
\hline \multirow{2}{*}{ Emotional stability } & 1 & 2001-2005 & -0.1 & - & -0.1 & - & 0.0 & - & ${ }^{\prime} 1^{\prime}=2^{\prime}=3^{\prime}$ & \multirow{2}{*}{$31^{\prime}>3 c^{\prime *}$} \\
\hline & 2 & 2010-2015 & -0.2 & -0.2 & -0.3 & -0.3 & -0.1 & -0.3 & ${ }^{\prime} 1{ }^{\prime}=1 c^{\prime} ; 2^{\prime}={ }^{\prime} 2 c^{\prime}$ & \\
\hline
\end{tabular}

Notes: in the last two columns sign «` marks the data of average increment of points for personality qualities of appropriate year students. Indices «1» and «2» after main symbol of group mean accordingly 2001-2005» and «2010-2015».

Questioning of $1^{\text {st }}-3^{\text {rd }}$ year students about five personality components at the end of academic year showed the following:

1. Students had positive changes of HLS personality components (in both time ranges). For three personality components of all years' students (except emotional stability and tolerance of $1^{\text {st }}$ and $2^{\text {nd }}$ years students) final progress was significantly higher than initial. Final tolerance level of $1^{\text {st }}$ and $2^{\text {nd }}$ year students did not differ significantly from initial. Concerning $3^{\text {rd }}$ year students of PC specialization, their final tolerance was significantly higher than initial (in both time ranges).

2. Positive changes of four HLS personality components (except self-confidence in 2010-2015) in all RHS groups of $1^{\text {st }}$ and $2^{\text {nd }}$ years differ insignificantly (in both time ranges). Positive change of self-confidence in RHS of $2^{\text {nd }}$ year was significantly higher than in RHS of $1^{\text {st }}$ year students. Further, these indicators did not change for students of PC specialization in 2010-2015. For 4 HLS personality components (except emotional stability) increment of personality components in $3^{\text {rd }}$ year PHS of PS specialization (in both time ranges) was much higher than in $1^{\text {st }}$ and $2^{\text {nd }}$ year students. For students of PS specialization such correlation was observed for 3 HLS personality components: positive state, self-confidence and activity.

3. Two HLS personality components (emotional stability and tolerance in respect to other people) in PS specialization students do not change during all period of study. In students of PC specialization emotional stability also does not change during first three years of study. In this category of students significant increment is observed only after 3 years of study (only in growth of self-assessment for tolerance to other people).

4. For specializations PC and PS we did not find significant difference for 4 personality components. Concerning fifth HLS component (self-confidence) in students of PC specialization after $2^{\text {nd }}$ year of study there 
appears a tendency of higher assessment of its level. In the aspect of HLS personality components' development PC trainings does not differ from typical classes by effectiveness.

5. Comparing of 2001-2005 and 2010-2015 data points at negative dynamic of HLS personality components development: in $3^{\text {rd }}$ year students - for all qualities of personality; in $1^{\text {st }}$ year students - for positive state and self-confidence. To larger extent it concerns $3^{\text {rd }}$ year students of specialization. It means that recent years training develops HLS personality components of most students less than 10 years ago. Besides, it was found that PC specialized trainings do not have advantages in development of student's personality in this direction.

\section{Discussion}

V.M. Rozin especially underlines: "Health can not be formed or built as a building. It can only grow but not without our efforts" [26].

At present time still more intensive application of health related technologies for students' HLS personality indicators prove the relevance of the present research. In this connection it is necessary to actualize solution of problems, hindering development of healthy life style personality components in students' education. Besides, it is necessary to take all measures for improvement of students' health components.

Students shall be offered clear steps to preservation optimal health; to keep positive mood [11]; to control the system of personal values; to creation of personal image, including physical, emotional and intellectual principles of young person's personality; to enrich practical philosophy of health, paying attention to mental and body development [8]. In every physical culture training it is necessary to strengthen students' motivation for healthy life style [28].

It is necessary to pay attention to the fact that physical culture and sports practicing are means of health improvement as well as physical perfection and rational leisure; mean of social activity rising. Such approach substantially influences on other sides of human activity: labor, moral and intellectual qualities.

Indeed, physical culture is one of main kinds of human culture. Its specificity is that this kind is profiled in direction of physical condition's optimization and individual's development in integrity with his/her psychic development. The basis of it are rational and effective usage of own motor functioning in combination with other cultural values [29].

The validity of the received results and approaches to creation of youth's healthy life style foundations is proved by works of other authors:

- About influence of sorts on personality's development [12];

- About morality, culture and youth's to-day's attitude to life problems' solution [4];

- About physical culture, as kind of human activity, specific features [1];

- Setting for creation of youth's healthy life style foundations [25].

Conception of human harmonious development shall also include unity, concordance and proportionality of "out-of-body", intrinsic only to human being qualities (will power, super-will power, morality, aesthetic, intellect) with all these in body and spirit integrity [12]. Modern students spend nearly all their time in virtual reality, where in different social sites they see ideal, handsome bodies of famous and ordinary people [4]. From this it follows that sport is now understood as fashion as compulsory component of healthy life style. As on to day sports have become one of fashionable directions of physical culture. However, it does not influence positively on students' attendance of learning and sport classes in higher educational establishments. Overloading with academic material requires significant strength, nervous and time losses from students. It forces students to neglect physical culture and sports as well as facilitates students' not seeing significance of physical development. In such cases students pay dominant attention to natural and humanitarian sciences. That is why the problem is to over-persuade students. It is necessary to prove that personality's development and directly human activity are impossible without successful physical development and physical fitness.

In context of the present work a relevant task is: formation of vitally important physical and motor qualities; perfection of psychic processes at levels: psycho-motor skills, thinking and imagination. It will be genuine care about youth; their personality's indictors, health and future professional workability.

The statement about possibility of students' character's development and hardening through physical culture and sports' practicing is undoubted. Such active position of sport-practicing and relatively healthy young 
people trains muscles and strengthens spirit. Comprehensively developed personality adapts to various modern conditions and successful future professional functioning quicker.

It is important to form attitude to sports [5, 7, and 22] as one of the main and integral values of young people's HLS. It will distract them from various harmful habits [19, 21]. Inculcation of such approach to youth's minds is important just at physical culture classes. [5, 20,23]. It will result in active mastering personal values of physical culture practicing as well as facilitate practicing fashionable and useful healthy life style [10, 22, and 28].

\section{Conclusions} development.

1. In any variant of physical culture classes personality qualities of young people have tendency to certain

2. Correlation of HLS personality components with period of study is not linear. To larger extent their development is observed at first and third years of study. The highest changes of HLS personality components are observed in $3^{\text {rd }}$ year students. These changes do not depend on the program of their training.

3. Trainings by specializations PC and PS influence approximately equally on development of students' HLS personality components.

4. At PC classes it is necessary to pay more attention to development of students' HLS personality components. Especially it concerns emotional stability and tolerance towards other people.

\section{Conflict of interests}

The authors declare that there is no conflict of interests.

\section{References:}

1. Aleksandrov SE. Specifika fizicheskoj kul'tury kak vida chelovecheskoj deiatel'nosti. Kand. Diss. [Specificity of physical culture as a kind of human activity. Cand. Diss.], Sankt Petersburg; 1993. (in Russian)

2. Aleshev NA. Formirovanie professional'no znachimykh kachestv u budushchikh inzhenerov sredstvami fizkul'turno-sportivnoj deiatel'nosti. Kand. Diss. [Formation of professionally important qualities in future engineers by means of physical culture-sports activity. Cand. Diss.], Cheboksary; 2007. (in Russian)

3. Anan'ev VA, Davidenko DN. Etiudy valeologii [Sketches on valueology], Sankt Petersburg: STU, BPA; 2001. (in Russian)

4. Bibler VS. Nravstvennost'. Kul'tura. Sovremennost': Filosofskie razmyshleniia o zhiznennykh problemakh [Morality. Culture. Nowadays: Philosophical speculations about life problems], Moscow: Knowledge; 1990. (in Russian)

5. Bliznevsky AA, Kudryavtsev MD, Iermakov SS, Jagiello W. Formation of active-effective attitude of 12-13 years' judo athletes to sports functioning in competition period. Archives of Budo, 2016; 12: 101-115.

6. Volozhanin SE. Povyshenie urovnia fizicheskoj podgotovlennosti studentov vuza sredstvami atletizma. Kand. Diss. [Increase of HEE students' physical fitness by means of athletics. Cand. Diss.], Ulan-Ude; 2007. (in Russian)

7. Gaskov AV, Kuzmin VA, Kudryavtsev MD, Iermakov SS. Successfulness of general and special physical qualities' development on different stage of students-boxers' training. Physical Education of Students, 2016;1:4-11. doi:10.15561/20755279.2016.0101

8. Diukov VM, Skurikhina NV. VUZ zdorovogo obraza zhizni [HEE of healthy life style], Lap Lambert Academic Publishing: Saarbrücken; 2013. (in Russian)

9. Kozina ZhL, Barybina LN, Kondak NN, Lisenko VV. Structure of complex preparedness of students women's of higher technical institute of different sporting specializations. Physical Education of Students, 2010;6;29-32.

10. Kondakov VL, Kopeikina EN, Usatov AN. On purposefulness of application of physical culture-health related technology for prophylaxis of students' respiratory system disorders. Physical Education of Students, 2016;20(2):4-12. doi:10.15561/20755279.2016.0201 
11. Kopylov YuA, Jackowska LN, Kudryavtsev MD, Kuzmin VA, Tolstopyatov IA, Iermakov SS. The concept of structure and content of health related trainings for higher educational establishments' students. Physical Education of Students, 2015;5:23-30. doi:10.15561/20755279.2015.0504

12. Korshunov IG. Vliianie sporta na razvitie lichnosti [Influence of sports on personality's development]. SCIARTICLE.RU, [Internet]. 2015 [cited 2016 Oct 29]; Available from: http://sciarticle.ru/stat.php?i=1450014277 (in Russian)

13. Kramida IE, Maksimov IaA. Izmenenie lichnostnykh pokazatelej zdorovogo obraza zhizni studentov v period auditornogo obucheniia na fakul'tete fizicheskoj kul'tury i sporta SibGAU [Change of personalities' indicators of students' healthy life style in period of auditorium study at physical culture and sports faculty of SibGAU]. Mezhdunarodnyj simpozium "Vostok - Rossiia-Zapad. Fizicheskaia kul'tura i sport, formirovanie zdorov'ia i zdorov'esberegaiushchie tekhnologii v sisteme obrazovaniia" [International symposium "East-Russia-West. Physical culture and sports; formation of health and health related technologies in system of education"], Krasnoyarsk: RIO KSU; 2006. P. 280-285. (in Russian)

14. Kramida IE. Valeologicheskij praktikum na osnove gimnastiki cigun kak faktor razvitiia lichnostnykh komponentov zdorovogo obraza zhizni u studentov [Valueological practicum on the base of Tci-gun gymnastic as factor of development of students' healthy life style personality components' development]. Vserossijskaia nauchno-prakticheskaia konferenciia "Aktual'nye problemy, mekhanizmy i perspektivy razvitiia fizicheskoj kul'tury i sporta $v$ vysshikh uchebnykh zavedeniiakh Minsel'khoza Rossii”" [All Russian scientific-practical conference "Current problems and prospects of physical culture and sports in higher educational establishments of Ministry of agriculture of Russia], Irkutsk: IrGSKHA; 2011. P. 255-259. (in Russian)

15. Kramida IE. Ozdorovitel'nyj praktikum na osnove gimnastiki cigun kak faktor formirovaniia zdorovogo obraza zhizni u studentov [Health improvement practicum on the base of Tci-gun gymnastic as factor of development of students' healthy life style personality components' development]. Vserossijskaia nauchnoprakticheskaia konferenciia "Optimizaciia uchebno-vospitatel'nogo i trenirovochnogo processa v uchebnykh zavedeniiakh vysshego professional'nogo obrazovaniia. Zdorovyj obraz zhizni, kak faktor profilaktiki narkomanii" [All Russian scientific-practical conference "Optimization of educational and trainings processes in educational establishments of higher vocational training. Healthy life style as factor of drugstaking prophylaxis"], Krasnoyarsk: Sibut; 2012. P. 353-356. (in Russian)

16. Kramida IE. Dynamics of personal development on healthy students. Pedagogics, psychology, medicalbiological problems of physical training and sports, 2013;4: 30-34. doi:10.6084/m9.figshare.691013

17. Kramida IE. Training workshop on the basis of gymnastic qigoing as a factor of personal development of students with poor health. Pedagogics, psychology, medical-biological problems of physical training and sports, 2013;4: 35-40. doi:10.6084/m9.figshare.691014

18. Kudryavtsev MD, Galimov GIa, Gas'kov AV. Obosnovanie effektivnosti uchebnykh zaniatij po fizicheskoj kul'ture s ozdorovitel'noj i obrazovatel'noj napravlennost'iu na osnove ocenki pokazatelej ispol'zovaniia elementov zdorovogo obraza zhizni [Substantiation of physical culture trainings, oriented on health improvement and education, effectiveness on the base of healthy life style elements' assessment]. Vestnik Buriatskogo gosudarstvennogo universiteta, 2012;13:121-124. (in Russian)

19. Kudryavtsev MD, Kramida IE, Kuzmin VA, Iermakov SS. Cieslicka Miroslawa, Stankiewicz Blazej, Influence of study in hee on ubiquity and strength of students' computer gambling. Physical Education of Students, 2016;3:13-22. doi:10.15561/20755279.2016.0302

20. Kudryavtsev MD, Galimov GIa, Kuzmin VA, Kopylov YA, Gas'kov AV. Effektivnost' ispol'zovaniia v sisteme fizicheskogo vospitaniia studentov netradicionnykh sredstv na primere khatkha-jogi [Effectiveness of non traditional means' usage in physical education system on example of Hatha Yoga]. Vestnik Buriatskogo gosudarstvennogo universiteta, 2014;1:41-44. (in Russian)

21. Kudryavtsev MD, Kramida IE, Iermakov SS. Influence of studying in higher educational establishment on students' harmful computer habits. Physical Education of Students, 2016;5:17-23. doi:10.15561/20755279.2016.0503 
22. Kuzmin VA, Kopylov YA, Kudryavtsev MD, Tolstopyatov IA, Galimov GY, Ionova OM. Formation of professionally important qualities of students with weakened motor fitness using a health related and sportoriented training program. Journal of Physical Education and Sport, 2016;16(1):136-145. doi:10.7752/jpes.2016.01023

23. Kuzmin VA, Kopylov YuA, Kudryavtsev MD, Galimov GY, Iermakov SS. Substantiation of effectiveness of trainings on health related methodic for students with weakened motor fitness. Physical Education of Students, 2015;6:43-49. doi:10.15561/20755279.2015.0606

24. Lubysheva LI, Bal'sevich VK. Cennosti fizicheskoj kul'tury v zdorovom stile zhizni [Physical culture values in healthy life style] Mezhdunarodnaia konferenciia "Sovremennye dostizheniia sportivnoj nauki" [International conference "Modern achievements of sport science”], Sankt Petersburg; 1994. P. 124-125. (in Russian)

25. Nazarova EN, Zhilov IuD. Osnovy zdorovogo obraza zhizni [Principles of healthy life style], Moscow: Academy; 2013. (in Russian)

26. Rozin VM. Koncepciia zdorov'ia [Conception of health], MSMSU; 2011. (in Russian)

27. Seliutina GV, Diukov VM. Prakticheskaia filosofiia zdorov'ia [Practical philosophy of health], Lap Lambert Academic Publishing: Saarbrücken; 2013. (in Russian)

28. Skurikhina NV, Kudryavtsev MD, Kuzmin VA, Iermakov SS. Fitness yoga as modern technology of special health groups' girl students' psycho-physical condition and psycho-social health strengthening. Physical Education of Students, 2016;20(2):24-31. doi:10.15561/20755279.2016.0204

29. Geleckij VM. Teoriia fizicheskoj kul'tury i sporta [Theory of physical culture and sports]. Krasnoyarsk: IPK SFU; 2008. (in Russian)

30. Trofimova OV. Sovershenstvovanie fizicheskogo vospitaniia studentok vuza na osnove uglublennogo izucheniia fitnes-aerobiki. Kand. Diss. [Perfection of HEE girl students' physical education on the base of profound study of fitness-aerobic. Cand. Diss], Cheboksary; 2010. (in Russian)

31. Chernenko SA. Description of how the specialization influences the dynamics of the functional and motor abilities among the third to fifth year female students. Physical Education of Students, 2012;4: 130 - 134.

32. Golovina VA, Masliakova VA, Korobkova AV. Fizicheskoe vospitanie [Physical education]. Moscow: High school; 1983. (in Russian)

33. Bliznevsky AA, Kudryavtsev MD, Iermakov SS, Jagiello W. Formation of active-effective attitude of 12-13 years' judo athletes to sports functioning in competition period. Archives of Budo, 2016;12: 101-115.

34. Gaskov A.V., Kuzmin A. V., Kudryavtsev D. M., Iermakov S. S., Successfulness of general and special physical qualities' development on different stage of students-boxers' training. Physical Education of Students, 2016;1:4-11. doi:10.15561/20755279.2016.0101

35. Iermakov SS, Arziutov GN, Jagiello W. Quick training of students to judo techniques. Archives of Budo, 2016;12:15-24.

36. Iermakov SS, Podrigalo LV, Jagiełło W. Hand-grip strength as an indicator for predicting the success in martial arts athletes. Archives of Budo, 2016; 12: 179-186.

37. Kopeikina EN, Drogomeretsky VV, Kondakov VL, Kovaleva MV, Iermakov SS. Modification of Harvard step-test for assessment of students' with health problems functional potentials. Physical Education of Students, 2016;20(4):44-50. doi:10.15561/20755279.2016.0405

38. Kozina ZL, Iermakov SS, Kadutskaya LA, Sobyanin FI, Krzeminski M, Sobko IN, Ryepko OA. Comparative characteristic of correlation between pulse subjective indicators of girl students' and school girls' reaction to physical load. Physical Education of Students, 2016;20(4):24-34. doi:10.15561/20755279.2016.0403

39. Kudryavtsev MD, Kopylov YuA, Kuzmin VA, Ionova OM, Yermakova TS. Personality oriented system of strengthening of students' physical, psychic and social-moral health. Physical Education of Students, 2016;20(3):58-64. doi:10.15561/20755279.2016.0308

40. Kudryavtsev MD, Kramida IE, Iermakov SS. Influence of studying in higher educational establishment on students' harmful computer habits. Physical Education of Students, 2016;20(5):17-23. doi:10.15561/20755279.2016.0503

41. Kudryavtsev MD, Kramida IE, Kuzmin VA, Iermakov SS, Cieslicka Miroslawa., Stankiewicz Blazej. Influence of study in hee on ubiquity and strength of students' computer gambling. Physical Education of Students, 2016;20(3):13-22. doi:10.15561/20755279.2016.0302 
42. Podrigalo LV, Iermakov SS, Alekseev AF, Rovnaya OA. Studying of interconnections of morphological functional indicators of students, who practice martial arts. Physical Education of Students, 2016;20(1):6470. doi:10.15561/20755279.2016.0109

43. Skurikhina NV, Kudryavtsev MD, Kuzmin VA, Iermakov SS. Fitness yoga as modern technology of special health groups' girl students' psycho-physical condition and psycho-social health strengthening. Physical Education of Students, 2016;20(2):24-31. doi:10.15561/20755279.2016.0204

Information about the authors:
Kudryavtsev M.D.; http://orcid.org/0000-0002-2432-1699;
kumid@yandex.ru; Siberian Federal University; 79 Svobodny
pr., Krasnoyarsk, 660041, Russia.; Siberian State Aerospace
University; Office A-406, 31, Krasnoyarsky Rabochy Av.,
660014, Krasnoyarsk, Russia.; Krasnoyarsk State Pedagogical
University of V.P. Astafyev; Ada Lebedeva Street, 89,
Krasnoyarsk, 660049, Russia.

Kramida I.E.; http://orcid.org/0000-0003-4256-2645; kramidai@mail.ru; Siberian State Aerospace University; Office A-406, 31, Krasnoyarsky Rabochy Av., 660014, Krasnoyarsk,Russia.

lermakov S.S.; http://orcid.org/0000-0002-5039-4517; sportart@gmail.com; Kazimierz Wielki University in Bydgoszcz; Sport str. 2, of.209, 85-064 Bydgoszcz, Poland.

Osipov A.Yu.; http://orcid.org/0000-0002-2277-4467; Ale44132272@ya.ru; Siberian Federal University; 79 Svobodny pr., Krasnoyarsk, 660041, Russia.; V.F. VoinoYasenetsky Krasnoyarsk State Medical University; P. Zeleznyak, 1, Krasnoyarsk, 660022, Russia.

Cite this article as: Kudryavtsev M.D., Kramida I.E., Iermakov S.S., Osipov A.Yu. Development dynamic of healthy life style personality component in relatively healthy students. Physical education of students, 2016;6:26-33. doi:10.15561/20755279.2016.0603

The electronic version of this article is the complete one and can be found online at: http://www.sportpedu.org.ua/html/arhive-e.html

This is an Open Access article distributed under the terms of the Creative Commons Attribution License, which permits unrestricted use, distribution, and reproduction in any medium, provided the original work is properly cited (http://creativecommons.org/licenses/by/4.0/deed.en).

Received: 29.10.2016

Accepted: 10.11.2016; Published: 28.12.2016 